\title{
Host-virus relationships with special reference to Newcastle disease and serum hepatitis
}

\author{
A. P. WATERSON \\ From the Department of Virology, Royal Postgraduate Medical School, London
}

To the patient and his doctor the typical virus infection is short in incubation, acute in course, and rapid in its progress to death or immunity. However, so far as the virus is concerned this arrangement is not necessarily either the optimum or the norm. It is not the optimum because no virus seeks host organisms which are dead or clinically immune. How far it is not the norm for virus infections is a more debatable point. It is true that classical virus infections such as measles, rubella, varicella, Newcastle disease, or viral hepatitis manifest themselves typically with such an illness, but for more than a hundred years it has been recognized, particularly by veterinarians, that some infections may be more prolonged in their course, including some now known to be viral. For example, a German veterinarian, Wörz, described as long ago as $\mathbf{1 8 5 8}$ the equine encephalitis called Borna disease as a 'semi-acute encephalitis'. More than $\mathbf{5 0}$ years ago it was known that horses with acute infectious anaemia might retain the infectivity in their blood for as long as seven years without either clinical illness or the development of clinical immunity in the sense of clearance of the virus. However, it was the study of several such lingering diseases of sheep in Iceland which led Sigurdsson to propound formally, in a series of classical papers published in the British Veterinary Journal in 1954, the concept of a 'slow' infection, in the sense of a disease process resembling in its chronological profile an acute infection elongated in time (Sigurdsson, 1954). This concept was distinguished from the idea of a chronic infection which might wax and wane in terms of a struggle between host and microorganism. Sigurdsson's concept has required some elaboration and modification, but essentially it has stood the test of time (Thormar, 1971).

\section{General Considerations}

This symposium is concerned with a set of phenomena which have one principal feature in common, namely, persistence or prolongation in time beyond what has in the past been considered usual for a virus infection. This prolongation may apply to the incubation period, to the illness itself, or to the continued presence of a virus in the host with no symptoms or signs of disease. It is in fact the title of the symposium which gives the clue to the wide variation, because there are two variables-the virus and the host-and so the interaction between these two is very widely variable indeed.

In addition, major developments both in virological knowledge and in medical technique have changed the whole picture radically in recent years in two respects. In the first place virological techniques have enabled a more intense scrutiny and a finer analysis of the processes of viral infection both in the cell and in the host as a whole. This has led to the realization that episodes of classical acute febrile illness can, in the case of many viruses, be part of a much longer-drawn-out pattern of events. A second development is that advances in medical technique have enabled patients to be kept alive while suffering from illnesses which would previously have been fatal, or to be maintained in a deliberately unphysiological state, for example, with the immune response suppressed to a greater or less degree.

\section{NEW KNOWLEDGE OF THE NATURAL HISTORY OF VIRUS DISEASES}

For many years it has been realized that an attack of varicella, for example, was no isolated episode, but rather a kind of virological priming by the varicella virus which often led eventually to episodes of a different clinical syndrome called herpes zoster. More recently, it has been realized that some otherviruses well known for their acute manifestations have equally complex natural histories. Rubella, once regarded as little more than a mildly troublesome disorder of childhood, has now assumed major importance not only as a cause of congenital malformations but as a model for the study of persistence 
of viral infection in the infant, and also of the mechanisms by which virus is eventually eliminated (Rawls, 1968; Banatvala, 1970). Herpes simplex is not simply a febrile cutaneous viral infection but a disease whose persistence throughout life raises questions of latency, as yet unanswered. In addition the severe acute generalized herpes infections of infancy contrast markedly with the behaviour of this same virus in the adult (Dudgeon, 1970). Even measles, which might be called the archetype of all the childhood fevers, is now implicated in the long drawn out childhood syndrome of subacute sclerosing panencephalitis, and has been isolated from the brains of children dying from the disease. The pathogenesis and epidemiology of the syndrome remain enigmatic, but the recent study of Brody, Detels, and Sever (1972) suggests that subacute sclerosing panencephalitis is in fact a rare individual host response to measles virus.

There is an interesting corollary to the realization that viruses best known as the causes of acute fevers have also chronic and persistent manifestations. It has been supposed that these same viruses may well be implicated in the aetiology of some of those chronic diseases whose causes are as yet quite unknown, such as multiple sclerosis, and a viral aetiology has been sought in an enormously wide range of illnesses from Crohn's disease to cardiomyopathies. Such searches are not all wild goose chases, and a successful example is the discovery that at least some cases of polyarteritis nodosa are attributable to serum hepatitis virus (Gocke, Morgan, Bombardieri, Lockshin, and Christian, 1970).

PARTICULAR CONSEQUENCES OF RECENT MEDICAL ADVANCES

The result of the therapeutic advances whose benefits are being reaped today is that the new survivors of therapeutic advances, or immunosuppressed patients, frequently manifest an entirely new virology and some of them are presenting with hitherto unobserved clinical syndromes caused by known viruses, eg, more florid manifestations of herpes virus, or of cytomegalovirus infections (Caul, Clarke, Mott, Perham, and Wilson, 1971). An example is the new group of uraemic patients who would previously have died of renal failure but are now kept alive by renal dialysis. Little is known about their response to infection, particularly to viral infections, but there are good grounds for supposing that they fare less well than comparable subjects with normal renal function, ie, that they are in a state of natural pathological immunosuppression. There are also patients who are artificially immunosuppressed, eg, those under treatment with corticosteroids or under more vigorous immunosuppressive therapy with cytotoxic drugs after transplant surgery, or as part of the therapeutic regime for leukaemia. In addition, and not unconnected with these latter developments, various new modes of transfer of viruses from one human being to another have arisen and are now widespread. These may give opportunities for the passage of an entirely new virus to man, eg, the Marburg agent, or for the efflorescence of an already known agent such as serum hepatitis virus. These involve principally the administration of blood products or the transfusion of blood itself, but they include also organ transplantation. Of course, a blood transfusion is not in fact conceptually different from an organ transplant, being essentially a short-lived and easily administered transplant, with an eventual planned rejection. Blood may itself be a source of viruses such as serum hepatitis (Turner, 1971) and cytomegalovirus (Kääriänen, Klemola, and Paloheims, 1966; Lang and Hanshaw, 1966) and, as a vehicle for the transfer of virus, blood is superior to a solid organ transplant because of the large volume of extracellular fluid involved.

\section{Populations of Cultured Cells as Models of Prolonged Infection}

Although advances in the technique of cell and tissue culture have made possible a fuller understanding of viral disease in general, they bear only a superficial resemblance to the situations seen in the intact infected organism, with its vascular circulation, intact cellular architecture, and various defence mechanisms. When there are inhibitory substances in a culture medium, the situation known as a 'carrier culture' may develop (Walker, 1964). Here there is persistent growth of the virus, even on serial subculture, but virus-free cells can always be recovered by cloning the culture. Although these are called 'carrier' cultures, the phenomenon is a model of the carrier state in the intact organism in vivo only in a limited sense.

Carrier cultures differ from what have been termed 'steady-state' cultures, in which there is continual production of virus and release of it from most cells, without cytocidal effect in any. Here too, there are variations. For example, the simian parainfluenza virus SV5 can grow in monkey kidney cells, and is released from them in high titre with no observable effect on the cells. The cells are apparently capable of handling and excreting the new viral protein without damage to themselves. Rubella virus, when first grown in cell cultures, caused no observable cytopathic effect, and it was necessary to detect its growth by the recognition of interference. This state of affairs is probably much nearer to the phenomenon of the continued presence of some 
viruses in the body in spite of the presence of antibody, eg, rubella. Rous sarcoma virus multiplies in chick embryo cells and, while it is not cytocidal, causes malignant transformation of the cells.

The large-scale use of monkey kidney cell cultures has shown that a wide variety of viruses may grow out from cultures of trypsinized cells, but probably most of these were viruses which happened to be present in the blood in the kidney or were trapped in the glomeruli. When the cells are washed, the virus is freed from the influence of antibody and is able to multiply. To sum up, therefore, studies in vitro can provide significant information which is applicable in the whole organism, at the cellular level, but populations of cells grown artificially are somewhat disappointing models for the events in the organism itself, or in a community of organisms as a whole.

\section{Variations in the Time Scale with Individual Viruses}

To return to the situation in the intact organism, two examples will be taken, viz, Newcastle disease in the fowl (Waterson, 1964; Allan, 1971) and serum hepatitis in man (Turner, 1971). Both of these were at first regarded as classical acute viral infections but in fact this now requires modification in both cases.

NEWCASTLE DISEASE IN THE FOWL

One of the chief biological interests of this infection is the occurrence of a multitude of different strains of virus, all of which are morphologically identical by electron microscopy (Waterson and Cruickshank, 1963) and, at least by presently available techniques, also serologically identical. However, when infecting the fowl (or other birds) they exhibit among themselves a complete range of variation in virulence (Waterson, Pennington, and Allan, 1967). Some are highly and uniformly lethal to adult birds, by involvement either of the nervous system or of the respiratory tract, while others enter into a peaceful and symptomless coexistence with the host and even with a host which is producing specific antibody to the virus. The virus may eventually be eliminated or may persist for long periods in the brain. The elucidation of the reasons for this range of variation in the biological effect of this virus has involved problems of methodology, In particular, it must be realized that a single pair of strains at opposite poles of virulence may vary also in other characteristics without this being any guarantee that these characteristics are associated with the differing virulence.

On the other hand, the selective use of two contrasting groups of strains with measured virulence, one group from either pole of the spectrum, has enabled an assessment of the features associated with the biological differences. It appears that the intracellular behaviour of the more clinically severe strains is characterized by irreversible damage to the lysosomal membranes of the cells (Allison and Mallucci, 1965), by a much greater modification of the cell surface (Reeve and Alexander, 1970; Reeve and Poste, 1971), and by the rapid production of virus-coded proteins some of which are as yet uncharacterized and which are probably not incorporated into the virion itself. The actual rates of viral growth are not different in the two types of strains but there appears to be a limitation of growth of viral antigens in the avirulent strains compared with the unrestrained accumulation of viral protein in the virulent ones (Reeve, Rosenblum, and Alexander, 1970). It has been suggested that virulent strains when multiplying in a cell shut off cellular protein and RNA synthesis and there is no question that several virulent strains do this (Reeve, Alexander, Pope, and Poste, 1971). However, there are some anomalies, and this last point is in need of further clarification (Moore, Lomniczi, and Burke, 1972).

The relevance to the present symposium is that Newcastle disease virus strains of extremely low virulence such as the Ulster and Queensland strains appear to persist in the host for longer periods than the more virulent ones which lead either to death or fairly rapid clearing by antibody. Antibody is produced in birds infected with these avirulent strains, but more slowly and to a lower titre than with more virulent strains. With strains of mild but low virulence, eg, strain $F$, there is infection of a high proportion of cells in the central nervous system without clinical neurological disease, and with the presence of circulating antibody in the blood. From studies of the events at the cellular level, it seems that the continued presence of virus in the host, particularly in the central nervous system, can be explained by the relative lack of damage to the host cell associated with viral multiplication, ie, that it approximates to the 'steady-state' situation described in artificial systems of cells. This is borne out by the fact that virulence in vivo is associated with high cytopathogenicity in vitro, while, conversely, strains which can set up prolonged symptomless infection, especially in the central nervous system, are those which do not seriously damage cells in vitro. Such strains should theoretically be ideal natural live virus vaccines, but in fact the antibody response is poor, probably because of the relatively small antigenic mass of the virus produced, and the bird after recovery is left with little or no clinical immunity.

So far as the host organism is concerned, there is little variation among fowls, and the major difference in response is seen with age, ie, strains which are quite harmless to the adult bird may kill a chick embryo of 10-day incubation. However, the principal 
differences in response are occasioned by the very wide variety of strains of virus. This contrasts sharply with several major naturally occurring human viruses, eg, poliomyelitis and measles. It appears to be occasioned by the non-incorporated but viruscoded proteins, which differ from strain to strain of NDV, whereas the proteins incorporated in the virion resemble each other.

\section{SERUM HEPATITIS IN MAN}

Although it is not yet possible to study the virus of serum hepatitis by culture in vitro, the discovery of the Australia antigen has opened a very wide door to the investigation of the diagnosis, natural history, and epidemiology of the disease (Zuckerman, 1969; Almeida, 1971). Here there is an interesting contrast with NDV. Admittedly little is known of strain differences in SHV, but it can be safely assumed for example that any one single outbreak in a renal dialysis unit is due to the same strain of virus, and the varying reactions of the individuals involved is studied on this basis. In fact, there is a very wide spectrum of clinical syndromes or none, following infection with the SH virus. Information is far from complete, but the variables seem to be with the host, particularly with his age, state of general health, and individual immune response. In discussing the various reactions, it will be assumed that these are the results of parenteral infections, although it is possible to infect patients orally (probably less efficiently) and also by air-borne spread (Almeida, Chisholm, Kulatilake, MacGregor, Mackay, O'Donoghue, Shackman, and Waterson, 1971).

\section{Healthy adult individuals}

After an incubation period which is long by usual standards, the subject may develop an acute attack of hepatitis with jaundice leading to recovery or death. Death may result from the action of antigenantibody complexes (Almeida and Waterson, 1969). A few of these patients progress to chronic active hepatitis or to cirrhosis although it is uncertain precisely what decides this particular outcome in any one patient.

\section{Uraemic patients}

The maintenance of uraemic patients in haemodialysis units, where outbreaks of serum hepatitis are particularly liable to occur, has enabled cases in staff and in patients to be studied both prospectively and in anticipation. In uraemic patients there is the same long incubation period as in healthy patients, and, as in non-uraemic patients there may be an acute illness with a fatal outcome. However, there are at least two other possibilities. The patient may become ill with jaundice, abnormal liver function tests, and have Australia antigen(Au-ag) in the blood. However, the illness may be drawn out over a period of several weeks or even months before recovery with final clearing of the Au-ag. In addition such patients may, after the appropriate incubation period, develop a subclinical infection with mildly abnormal liver function tests and have Au-ag in their blood but no marked departure from their general level of health. Experience with renal dialysis patients who recover and subsequently come in contact again with serum hepatitis suggests that they have a clinical immunity in spite of the undetectability of circulating antibody to the Au-ag in their blood.

\section{Serum hepatitis in childhood}

The occurrence of antibody to Au-ag in haemophiliacs suggests that at least some of these have an asymptomatic infection with serum hepatitis virus. They rarely give a clinical history of an acute attack of hepatitis. Parallel experience with children given icterogenic human serum as a component of yellow fever vaccine (Fox, Manso, Penna, and Madureira Para, 1942) suggests that, although a child may have a frank and fatal attack, it is much more likely to have an asymptomatic infection. The findings of Sutnick, London, Gerstley, Cronlund, and Blumberg (1968) in children with Down's syndrome bear this out. How many of these patients become asymptomatic carriers is not known, but, as they have by this age a well functioning, antibody-producing system, it is likely that they will become immune rather than tolerant.

\section{Serum hepatitis in the neonate}

The newborn infant may be infected from a mother containing the Au-ag in her blood. In fact birth is impossible, either vaginally or by Caesarian section, without the infant being heavily contaminated with maternal blood. Indeed, it seems that there is no other natural process in the whole gamut of human experience where one individual is exposed so liberally to the blood of another.

The infected mothers fall into two categories. They may be suffering from frank clinical hepatitis during pregnancy or at the time of delivery, as in the mother reported by Turner, Field, Lasheen, Todd, White, and Porter (1971), who became jaundiced the day before delivery. This patient's baby remained clinically well with no jaundice, but developed a positive Au-ag test and raised serum enzyme levels, having last been seen at 2 years of age, at which time it was still $\mathrm{Au}-\mathrm{ag}$ positive but with somewhat more normal liver function. The case reported by Wright, Perkins, Bower, and Jerrome (1970) concerned an infant who developed jaundice followed by cirrhosis, and has subsequently died It is also 
possible for infants to be infected from mothers who are incubating serum hepatitis at the time of delivery and develop overt hepatitis after childbirth (Schweitzer and Spears, 1970). These are essentially similar to the mothers ill with hepatitis late in pregnancy.

The other category of expectant mother is the symptomless carrier. These may produce infants who become clinically ill, with subsequent death from cirrhosis, as in the patient of Stokes et al (1954) or one reported by Gillespie, Dorman, Walker-Smith, and Yu (1970), or they may produce a child who is also a symptomless carrier, as reported by Smithwick and Go (1970). This latter category (of the carrier mother producing the carrier infant) would, before the days of Australia antigen, be likely to have gone undetected, and Turner (1971) has summarized the evidence that such a train of events may be the most frequent genesis of the silent carrier state. There is at present no evidence for the transplacental transfer of serum hepatitis virus. Yet another manifestation of serum hepatitis infection may be entirely extrahepatic, at least in its clinical features, viz, those cases of polymyositis and polyarteritis nodosa with renal failure described by Gocke et al (1970). These may have abnormal liver function tests and abnormal histological findings on biopsy.

There are still a good many pieces of the serum hepatitis jigsaw to be fitted into place but already it is clear that the reaction to the same virus in terms of clinical effect, which may be nil, can differ widely from patient to patient, varying with age, perhaps with dose, and certainly with the state of general health and the immunological status of the patient. While some of the reasons for this variation are clear, eg, the different picture seen in the uraemic patients, others, particularly the predilection in some patients for extrahepatic manifestations, are far from clear.

\section{Variables and their Interaction}

The two examples which have just been detailed show that the varying result of the interaction of the virus and host may be either with the virus or with the host. The first example (NDV) depended mostly on the virus, the second (SHV) on the host. It is therefore unwise to think of 'slow viruses' (or the opposite) as though there are some fixed and immutable patterns of reaction to particular viruses, which cause reproducible syndromes with regularity. The outcome of any particular virus infection depends on the combination of a number of independent variables. Admittedly, the virus concerned is one of these, but the route of infection and the characters of the individual host organism are at least as important.

\section{THE VIRUS}

The type of virus itself

Various morphological types of virus have been involved in prolonged infections and also some agents which are much less well characterized. Others are not even beyond the stage of being 'transmissible filterable agents', eg, agents such as potato spindle tuber virus, which has the properties of an unusually stable, free RNA (Diener, 1971). It has been suggested that the enveloped RNA viruses whose particles are formed by budding from the cell surface, and which frequently have oncogenic potential, may be particularly prone to persist in the host, but they clearly have no monopoly of the phenomenon, Ability to infect and damage, or at least to cause dysfunction of, immunocytes, may be an important quality, as is probably the case with, for example, rubella in the neonate, and may also be a factor in measles (Kempe and Fulginiti, 1965; Enders-Ruckle, 1967).

\section{Strain differences}

This has already been referred to in connexion with NDV. This is the basis of vaccination with live virus vaccines, some of which may persist in the body, and be excreted, for long periods. It is the attenuated, relatively avirulent forms of a virus which are particularly suited for setting up a low-grade chronic infection with effects which may beapparentonly after a period of years (Waterson and Almeida, 1969). These effects may not be connected by the observer with the original virus infection.

\section{Dose of virus}

This may affect the outcome, and it may affect the period of incubation. Certainly the dose of virus administered may vary widely and in the case of serum hepatitis it may be relatively enormous by viral standards. For example, the transfusion of, say $\mathbf{4 5 0}$ $\mathrm{ml}$ of icterogenic blood, or the administration of $20-40 \mathrm{ml}$ of serum hepatitis-contaminated convalescent measles serum (Waterson, 1972) would be regarded, in experimental terms, as a very high inoculum.

THE ROUTE OF ADMINISTRATION

With modern techniques of immunosuppression, it is probably more frequent than ever before for an unrecognized endogenous virus infection to be lighted up, particularly, it seems, a herpesvirus or a cytomegalovirus. Transplanted organs, especially kidneys, are potential sources of viruses to the 
recipients, as are the considerable blood transfusions accompanying transplant operations. Infection in utero is an important consideration, no less so because it may be inapparent. Parenteral physical injection has been practised for many centuries by biting arthropods, and for somewhat shorter periods by practising physicians. In connexion with the dose, the question of oral or respiratory receipt of virus may be decisive in determining whether or not there is illness, eg, the acid sensitivity of rhinoviruses is considered to determine their inability to cause infection of the intestine, because they are likely to be inactivated in the stomach.

\section{THE INDIVIDUAL HOST}

The importance of species goes without saying. Herpes simplex may be a trivial infection in most humans, at least in adult life, but may cause a fatal encephalitis in most rabbits when inoculated into them. Age of exposure, including age before birth, is important, not so much in determining the infection, but in deciding the clinical form of the outcome. The immunological state of the individual is obviously important, viz, whether he has been infected before, whether he has been artificially immunized, and, if so, by what sort of vaccine. At the other end of the scale, it is obviously of relevance whether or not he is under immunosuppression, or suffers from inherited or acquired immune deficiencies. Both immune deficiencies as well as previous immunization can be harmful in certain cases.

\section{Conclusion}

The biological phenomenon of viral infection, whether observed in medical practice, veterinary practice, or experimentally, is a result of a complicated set of interactions involving many variables. The degree of disturbance to the host organism may vary from none at all to rapid death, but, in between these, the time scale involved may vary greatly from virus to virus, or even with one virus, and may vary greatly from one individual to another even of the same species. It is the long end of this time spectrum with which we must be concerned in a consideration of any but the rapidly developing and rapidly resolving type of viral infection. The prolonged type of infection, with or without overt symptoms, occurs so frequently that it may eventually prove to have as good a claim to be regarded as the norm as has the classical acute viral infection.

The author is in receipt of a grant from the Agricultural Research Council in aid of the research on Newcastle disease virus. He is indebted to several colleagues, in particular to Drs Peter Reeve and George Poste, of this department, and $\mathrm{Mr} \mathrm{W}$. H. Allan, of the Central Veterinary Laboratory, Weybridge, for critical discussion of the section concerning this disease. Work on serum hepatitis in this department has been supported by a grant from the Department of Health and Social Security. The author acknowledges with gratitude the constructive comments of Dr June Almeida on the section on serum hepatitis and with regard to the paper as a whole.

\section{References}

Allan, W. H. (1971). The problems of Newcastle disease. Nature (Lond.), 234, 129-131.

Allison, A. C., and Mallucci, L. (1965). Histochemical studies of lysosomes and lysosomal enzymes in virus-infected cell cultures J. exp. Med., 121, 463-476.

Almeida, J. D. (1971) Electron microscopic observations and speculations on Australia antigen. Postgrad. med. J., 47, 484-487.

Almeida, J. D., and Waterson, A. P. (1969). Immune complexes in hepatitis. Lancet, 2, 983-986.

Almeida, J. D., Chisholm, G. D., Kulatilake, A. E., MacGregor, A. B., Mackay, D. H., O'Donoghue, E. P. N., Shackman, R., and Waterson, A. P. (1971). Possible air-borne spread of serum-hepatitis virus within a haemodialysis unit. Lancet, 2, 849-850.

Banatvala, J. E. (1970). Rubella. In Mcdern Trends in Medica Virology, 2nd ed., edited by R. B. Heath and A. P. Waterson, pp. 116-163. Butterworth, London.

Brody, J. A., Detels R., and Sever, J. L. (1972). Measles-antibody titres in sibships of patients with subacute sclerosing panencephalitis and controls. Lancet, 1, 177-178.

Caul, E. O., Clarke, S. K. R., Mott, M. G., Perham, T. G. M., and Wilson, R. S. E. (1971). Cytomegalovirus infections after open heart surgery. Lancet, 1, 777-781.

Diener, T. O. (1971). A plant virus with properties of a free ribonucleic acid: potato spindle tuber virus. In Comparative Virology, edited by K. Maramorosch and E. Kursoak. pp. 433-478. Academic Press, New York.

Dudgeon, J. A. (1970). Herpes simplex. In Modern Trends in Medical Virology, 2nd ed., edited by R. B. Heath and A. P. Waterson, pp. 78-115. Butterworth, London.

Enders-Ruckle, G. (1967). Some characteristics of immunity following natural measles and various forms of immunization. Arch. ges. Virusforsch., 22, 23-34.

Fox, J. P., Manso, C., Penna, H. A., and Madureira Para (1942). Observations on the occurrence of icterus in Brazil following. vaccination against yellow fever. Amer. J. Hyg., 36, 68-116.

Gillespie, A., Dorman, D., Walker-Smith, J. A., and Yu, J. S. (1970) Neonatal r.epatitis and Australia antigen. (Letter.) Lancet, 2, 1081 .

Gocke, D. J., Hsu, K., Morgan, C., Bombardieri, S., Lockshin, M., and Christian, C. L. (1970). Association between polyarteritis and Australia antigen. Lancet, 2, 1149-1153.

Kääriänen, L., Klemola, E., and Paloheimo, J. (1966). Rise of cytomegalovirus antibodies in an infectious-mononucleosis-like syndrome after transfusion. Brit. med. J., 1, 1270-1272.

Kempe, C. H., and Fulginiti, V. A. (1965). The pathogenesis of measles virus infection. Arch. ges. Virusforsch., 16, 103-128.

Lang, D. J., and Hanshaw, J. B. (1969). Cytomegalovirus infection and the postperfusion syndrome. New Engl.J. Med., 280,1145-1149.

Moore, N. F., Lomniczi, B., and Burke, D. C. (1972). The effect of infection with different strains of Newcastle disease virus on cellular RNA and protein synthesis. J. gen. Virol., 15, 99-101.

Rawls, W. E. (1968). Congenital rubella: the significance of virus persistence. Progr. med. Virol., 10, 238-285.

Reeve, P., and Alexander, D. J. (1970). Plaque formation, cell fusion and haemadsorption by Newcastle disease virus. Cytobios, 5 , 55-57.

Reeve, P., and Poste, G. (1971). Studies on the cytopathogenicity of Newcastle disease virus: relation between virulence, polykaryocytosis and plaque size. J. gen. Virol., 11, 17-24. 
Reeve, P., Alexander D. J., Pope, G, and Poste, G. (1971). Studies on the cytopathic effects of Newcastle disease virus: metabolic requirements. J. gen. Virol., 11, 25-34.

Reeve, $P_{e,}$ and Rosenblum, M., and Alexander, D. J. (1970). Growth in chick chorioallantoic membranes of Newcastle disease virus of differing virulence. J. Hyg. (Lond.), 68, 61-69.

Schweitzer, I. L., and Spears, R. L. (1970). Hepatitis-associated antigen (Australia antigen) in mother and infant. New Engl. $J$. Med., 283, 570-572.

Sigurdsson, B. (1954). Rida, a chronic encephalitis of sheep, with general remarks on infections which develop slowly and some of their special characteristics. Brit. vet. J., 110, 341-354.

Smithwick, E. M., and Go, S. C. (1970) Hepatitis-associated antigen in cord and maternal sera. (Letter), Lancet, 2, 1080-1081.

Stokes, J., Jr. et al (1954). The carrier state in viral hepatitis. $J$ Amer. med. Ass., 154, 1059-1065.

Sutnick, A. I., London, W. T., Gerstley, B. J. S., Cronlund, M. M. and Blumberg, B. S. (1968). Anicteric hepatitis associated with Australia antigen: occurrence in patients with Down's syndrome. J. Amer. med. Ass., 205, 670-674.

Thormar, J. (1971). Slow infections of the central nervous system. $Z$. Neurol., 199, 1-23 and 151-166.

Turner, G. C. (1971). Infectious and serum hepatitis. Brit. J. Hosp. Med., 5 206-312.
Turner, G. C., Field, A. M., Lasheen, R.!M., Todd, R. M., White, G. B. B., and Porter, A. A. (1971). SH (Australia) antigen in early life. Arch. Dis. Childh., 46, 616-622.

Walker, D. L. (1964). The carrier state in animal cell cultures. Progr. med. Virol., 6, 111-148.

Waterson, A. P. (1964). The morphology and composition of Newcastle disease virus. In Newcastle Disease Virus: An Evolving Pathogen Madison, 1964, edited by R. P. Hanson, pp. 119-132. University of Wisconsin Press, Madison abd Milwaukee.

Waterson, A. P. (1972). Serum hepatitis and the seroprophylaxis of measles. $Z$. Naturforsch, 27b, 233-241.

Waterson, A. P., and Almeida, J. D. (1969). Virological aspects of neurological disease. Postgrad. med. J. 45, 351-360.

Waterson, A. P., and Cruickshank, J. (1963). The effect of ether on Newcastle disease virus: a morphological study of eight strains. Z. Naturforsi:h., 18b, 114-118.

Waterson, A. P., Pennington, T. H., and Allan, W. H. (1967). Virulence in Newcastle disease virus: a preliminary study. Brit. med. Bull. 23, 138-143.

Wright, R., Perkins, J. R., Bower, B. D., and Jerrome, D. W. (1970). Cirrhosis associated with the Australia antigen in an infant who acquired hepatitis from her mother. Brit. med. J., 4, 719-721.

Zuckerman, A. J. (1969). Viral hepatitis and the Australia-SH antigen. Nature (Lond.), 223, 569-572. 